\title{
Seeing Race in Biblical Egypt: Edwin Longsden Long's Anno Domini (1883) and A. H. Sayce's The Races of the Old Testament (1891)
}

Debbie Challis ${ }^{1, *}$

How to cite: Challis, D. 'Seeing Race in Biblical Egypt: Edwin Longsden Long's Anno Domini (1883) and A. H. Sayce's The Races of the Old Testament (1891)'. Papers from the Institute of Archaeology, 2019, 28(1): pp. 1-22. DOI: 10.14324/111.2041-9015.006

Published: 08/07/2019

\section{Peer Review:}

This article has been peer reviewed through the journal's standard double-blind review.

\section{Copyright:}

(C) 2019, The Author(s). This is an Open Access article distributed under the terms of the Creative Commons Attribution License (CC-BY) 4.0 https://creativecommons.org/licenses/by/4.0/, which permits unrestricted use, distribution and reproduction in any medium, provided the original author and source are credited • DOI: [https://doi.org/10.14324/111.2041-9015.006].

\section{Open Access:}

Papers from the Institute of Archaeology is a peer-reviewed open access journal. 


\title{
RESEARCH PAPER
}

\section{Seeing Race in Biblical Egypt: Edwin Longsden Long's Anno Domini (1883) and A. H. Sayce's The Races of the Old Testament (1891)}

\author{
Debbie Challis
}

\begin{abstract}
This paper discusses the impact of ideas about the historical and racial origins of the Holy Family that are captured in the painting Anno Domini or the Flight into Egypt (1883/4) by Edwin Longsden Long. Anno Domini fits into a wider $19^{\text {th }}$-century popular visual and literary narrative around Egypt and its ancient and biblical past. This general narrative, and its racial constructions, has been explored within reception theory and art history, but often overlooked in histories of archaeology and Egyptology. This paper unpacks how Anno Domini fits into a well-known orientalist way of seeing Egypt but also reflects ideas about race that were prevalent in archaeology and other newly established scientific disciplines at the time. The construction of the Virgin Mary and Christ child as White Europeans in Anno Domini both reflects and had an impact on constructions of race in Britain and on ancient (and modern) peoples in the Holy Land and Egypt in the late nineteenth century.

These constructions fed the growing use of scientific terminology to give such racist imagery authority, as found in A. H. Sayce's 'Sunday school book' The Races of the Old Testament (1891). Sayce's popular book used photographs taken by the archaeologist Flinders Petrie in 1887 of different 'racial types' from Egyptian monuments. Anno Domini vividly illustrates the preoccupation with race and identity found in archaeological interpretations of and motivations for recording material culture from ancient Egypt. This paper illustrates how art, archaeology, orientalism and racial theory fused and fed each other.
\end{abstract}

Keywords: Racial Theory, Orientalism, Victorian art, Ancient Egypt, history of archaeology, Flinders Petrie

\section{Introduction}

Anno Domini or the Flight into Egypt by Edwin Longsden Long depicts the Virgin Mary as a golden-haired pale young woman with a classical sculptural profile holding Jesus Christ, a fair-haired child, while sitting on a donkey led by Joseph, a darker skinned and bearded man. They pass traders selling shabtis and Egyptians using amulets to heal a sick child. In the background is a procession of worshippers carrying a statue of the goddess Isis suckling the infant Horus. In the distance, an Egyptian pylon temple can be seen behind 
which, incongruously, the shapes of the three pyramids can be distinguished (Figure 1) ${ }^{1}$. This painting vividly illustrates the nature of religious interest in Egypt as well as the assignment of a white European racial identity to the Virgin Mary and Jesus Christ. Arguably the diverse ethnic groups are depicted as different 'racial types' in much the same way as various objects - background, shabtis, trumpets, jewellery - are used to position period and place. Anno Domini generated much high profile and public interest on first being exhibited in the winter of 1883/84 and continued to be on display to the public, for a fee, for a further thirteen years. Now on display for free in the Russell-Cotes Art Gallery and Museum in Bournemouth, it is not only a work of epic proportions and content but also a work that captures the interest in the historical and racial origins of the Holy Family at a particular moment in British culture.

Anno Domini fits into a wider $19^{\text {th }}$-century popular visual and literary narrative around modern Egypt and its ancient and biblical past. Two illustrated books, published almost simultaneously in the 1830s, heavily influenced the genre of Orientalist art depicting antiquity in which Anno Domini belongs. E. W Lane's An Account of the Manners and Customs of the Modern Egyptians (1836) became a 'reference point for many artists' in depicting the diversity of people in Egypt (Llewellyn, 2006: 40); while John Garner Wilkinson's Manners and Customs of the Ancient Egyptians (1837, republished 1878) provided 'pullouts' of design and domestic and public furniture (Esposito, 2003: 85). In January 1884, soon after Anno Domini was first displayed, The Magazine of Art ran a feature by the historian W. J. Loftie on 'Egyptian Types', in which he wrote about the different turbans, costumes and complexions of modern Egyptians with illustrations of each (Figure 2). Loftie contrasted the different 'types' of Egyptians to the Syrians, Greeks, and Maltese who lived in Alexandria and other parts of Egypt, singling out the Bedouin people for their 'wild appearance and strange appearance' (Loftie, 1884, 15). He noted that the Bedouin appeared to be racially unique to Egypt and as such were singled out as models by the 'numerous European artists who yearly visit Egypt' (Loftie, 1884: 60). In the same issue, the magazine reviewed Long's 'fresh but ineffective' depiction of the Flight to Egypt; while admiring the study of the Holy Family, the sunset and set piece of Egypt, the reviewer found the composition stilted and 'Academical' ('Art in January' 1884: xiv).

1 Edwin Longsden Long, Anno Domini (1883): https://commons.wikimedia.org/wiki/File:Edwin_Longsden_Long_Anno_Domini.jpg [accessed 01/05/2019] 
However, the juxtaposition of Egyptian Types with Anno Domini in the same journal points to an absorbing interest in depicting racial types in the late nineteenth century. ${ }^{2}$

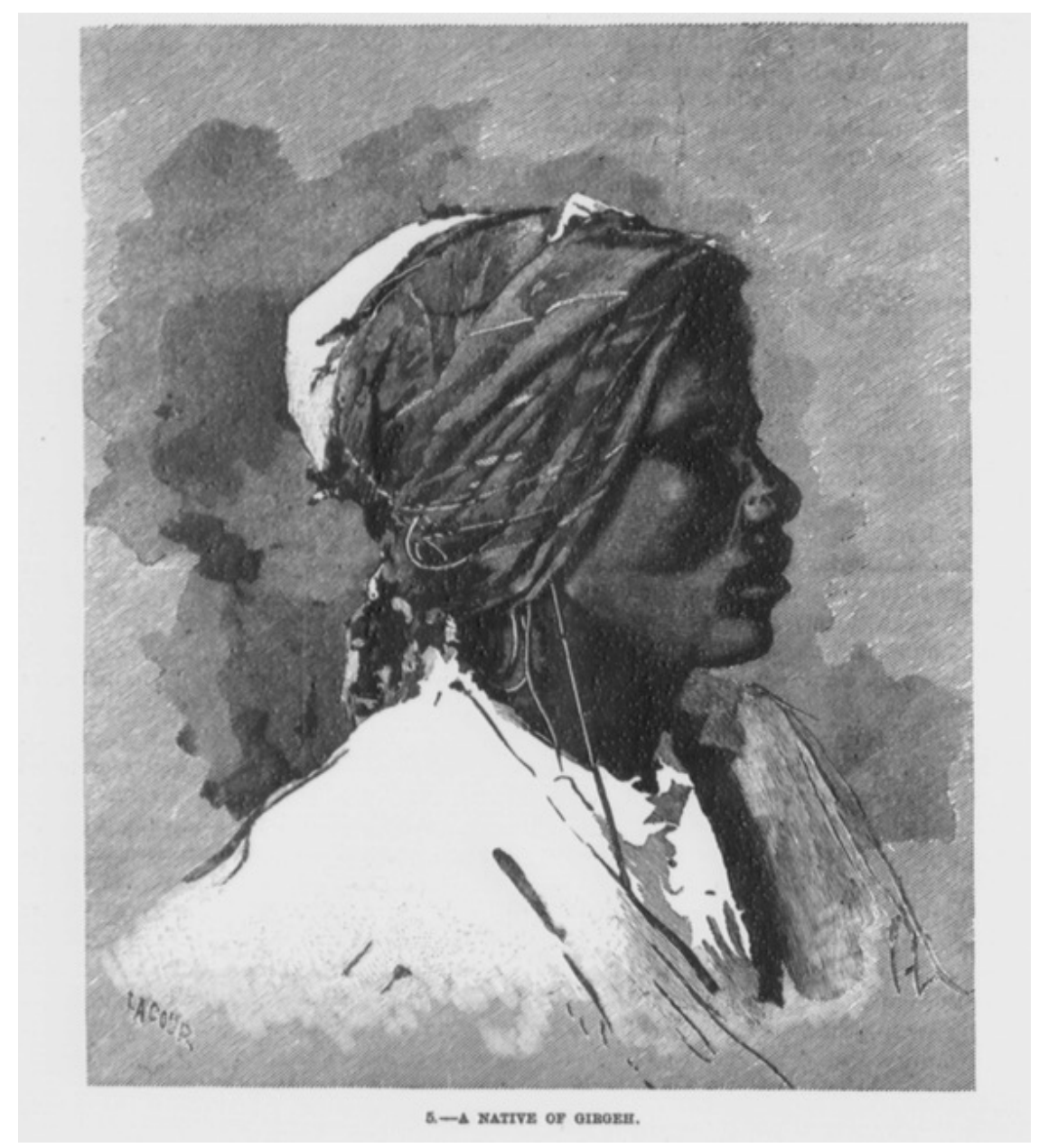

Figure 2: ‘A Native of Girgeh’ (Loftie 2884: 60).

By the late 1870s a visit to Egypt and the Holy Land had become almost a rite of passage for artists depicting antiquity, the Bible and the Orient. Artists from David Roberts in the 1830s to Holman Hunt in the 1850s to Frederick Goodall in the 1860s and 70s -just to pick out three British artists - established certain conventions in constructing these scenes. Artists attempted to authenticate the past by travelling to the places they represented but their vision was filtered by modern western ideas about those lands and antiquity. Anno

\footnotetext{
2 'Racial types' is in this paper used to refer to race or ethnicity as discussed in the late nineteenth century, noting that race is a scientifically defunct term but that racism is not.
} 
Domini fits into a well-known orientalist way of seeing ancient and modern Egypt as well as picturing Egypt within a popular biblical narrative (Nochlin 1983; Gange 2013).

In this paper, I argue that the painting also reflects ideas about racial typology and physiognomy that were prevalent in art, literature and travel writing on Egypt and the Holy Land throughout the $19^{\text {th }}$ century. ${ }^{3}$ This ethnographic way of seeing Egypt is not unique to Anno Domini. Long's painting was informed by and informed interest in defining race in Ancient Egypt and the Holy Land in the mid to late $19^{\text {th }}$ century. The construction of racial types and interest in racial heritage became established as a (pseudo) science by the early $20^{\text {th }}$ century, feeding the eugenics movement and imperialism. An example of this growing use of scientific terminology to give racial construction authority can be found in A. H. Sayce's 'Sunday school book' The Races of the Old Testament (1891), which used photographs taken by Flinders Petrie in 1887 of different 'racial types' from Egyptian monuments. Both Anno Domini and The Races of the Old Testament vividly illustrate not just religious interest but also the preoccupation with race and identity in visions of ancient (and contemporary) Egypt.

\section{Authenticating Antiquity in Art and Travel}

Travel and the experience of going to the regions depicted in Orientalist painting was important for establishing oneself as an authentic artist in the genre. Growing numbers of artists and photographers visited Egypt and Holy Land as a rite of artistic passage. This Grand Tour became more popular after the visit to the Greek Islands, Istanbul, Holy Land and Egypt by the Prince of Wales (later Edward VIII) in 1862 and the display of photographs of this tour by Francis Bedford later the same year (El Hage 2013: 46). Edwin Longsden Long joined the growing group of Orientalist British artists relatively late as he did not visit Egypt and Syria until 1874 (Hanley 2010: 20). Long's contemporary Edward Goodall had visited Egypt in 1858, while the leading Pre-Raphaelite artist Holman Hunt travelled to Egypt and the Holy Land in the early 1850s. David Roberts had preceded these artists by several decades and was perhaps the most prolific illustrator of Egypt and the Middle East, setting a pattern for exhibiting paintings and having lucrative lithographs made (Moscrop 2000: 23).

\footnotetext{
${ }^{3}$ In this paper Egypt refers to the geographical and political entity that the country is today and was in the Nineteenth Century. The admittedly nebulous and contentious term Holy Land is used to refer to the region understood by the Victorians to be where the main incidents of the Bible happened outside of Egypt, parts of which are in the contemporary countries of Israel, Syria, Iraq, Jordan, Lebanon, and the Palestinian territories.
} 
Arguably by the late 1850s, photographs captured the sweeping landscapes and 'monuscapes' with the tiny human and animal figures inserted for scale, colour and veracity that had characterized Roberts' work. Instead artists focused on the people (and sometimes animals) of the lands pictured, depicting a seemingly changeless Egypt and the Holy Land that, in the words of Linda Nochlin, created an 'oriental reality'. This could be applied to ethnography and racial construction as much as to the landscape and ruined ancient monuments (Scott 1988: 5). The French artist Ferdinand-Eugene-Victor Delacroix, having visited Morocco in 1832, famously declared that 'living antiquity' could be seen in the Arab and Jewish communities there. Although he:

Attempted to resist the phenomenon of racial mixing by utilizing isolated rather than blended zones of colour when depicting the Arabs, Jews and blacks of Algeria and Morocco (Grindhart 2008: 226).

Artists had seen ancient and biblical past in the faces of the people in North Africa and the Middle East since the early $19^{\text {th }}$ century but, arguably, it was Holman Hunt who did the most to cultivate the idea of the 'artist ethnographer', whether drawing ancient or modern scenes. Interestingly, similarly to Delacroix, Hunt sought out pure Jewish or other types for his work, decrying the racial mixing in Jerusalem and Cairo.

Hunt's 'cultural cross-dressing' and 'oriental mania' has been well documented, though he was as interested in depicting supposed differences of race as much as an imagined Orient (Boime 2002: 94). Hunt's The Light of the World (1851-3) was perceived to stress the Jewish origins of Jesus through physiognomy as well as symbolism and was completed before he left for the Holy Land. In Hunt's absence, the art and social critic John Ruskin vigorously defended the painting for its realism (Boime 2002: 99-100). In Jerusalem Hunt attempted to draw living people as models for his The Finding of the Saviour in the Temple (1854-60) but managed to inflame religious sensitivities in doing so. He was trying to accurately depict the biblical scene in terms of décor, light, furnishings, costume and racial types. This painting was analysed minutely in an article 'Art in Relation to Comparative Anthropology' in the Anthropological Review in 1867, in which the writer found that the figure of Christ was 'physically and phrenologically incorrect' (Cowling 1989: 111). Hunt eschewed the decaying fashion for phrenology and the idealised head for the founder of Christianity for the supposed realism of blood and racial type. 
Hunt's mission as an artist ethnographer was not one that all artists aspired to, but the idea of capturing authentic depictions of people as much as landscape or architecture became influential. It was a quality that was stressed in reviews of artists' work during the period. For example, Frederick Goodall's The First Born (1862) was reviewed in the Illustrated London News by referring to his travels to Egypt in 1858-9:

A gentleman who was with the artist at the time tells us that the swarthy model was a Copt woman from the "Christian" or "Copt Quarter" of Cairo and that the fine type and form of these women are not exaggerated. ('The First Born' 1862: 145).

Goodall's Rebekah at the Well (1880), made after his second visit to Egypt in 1870, was described in the same journal as having a face 'with its dark rich tinge' is 'such as we naturally associate with the Orient':

Her costume, her water-jars and the well with its domical roof, are, or at least the latter are precisely what Mr Goodall has seen in his journeys to the Holy Land. ('Rebekah at the Well' 1880: 597)

This focus is reflected in a series on 'The Land of Egypt' in The Art Journal by Edward Thomas Rogers, a former British Consul of Cairo, and his sister Mary Eliza Rogers, with drawings by George Seymour, regularly included images and written accounts of the people (Figure 3). In 'Chapter XI: Character of Egyptians' the Rogers contend that the character of the modern Egyptians, particularly the 'patient peasants [are] unchanging from the time of the pharaohs' (Rogers, Rogers \& Seymour 1879: 356). The inclusion of these kind of descriptions and images in The Art Journal attest to the value for an artist to have seen the lands and people of Egypt and the Holy Land for themselves and give a glimpse of the context in which Long and others worked. 


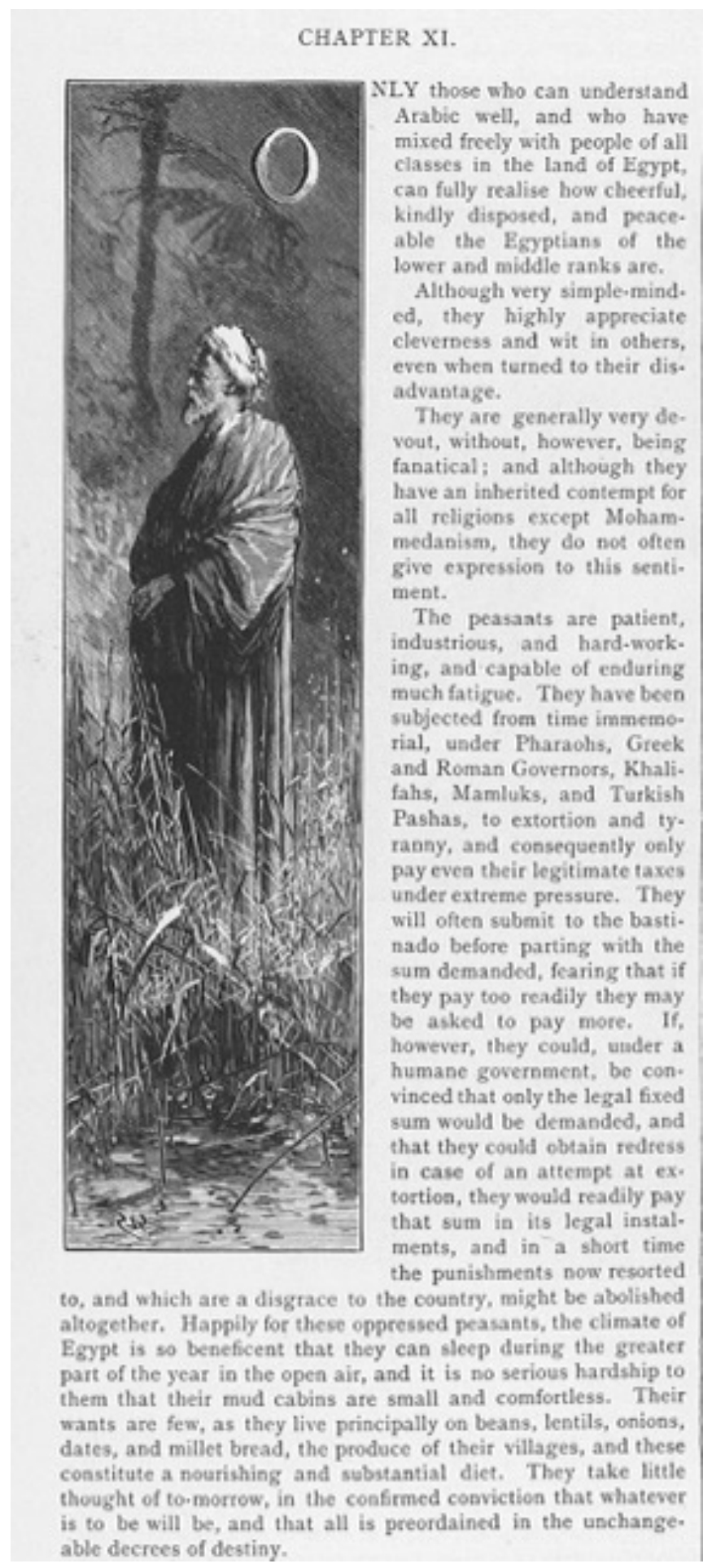

Figure 3: George Seymour, Title Illustration, from 'The Land of Egypt: Chapter XI' (Rogers 1879: 356). 
In Chapter III the Rogers speculate on the route of the Exodus across Egypt underlining the importance of the Bible in the $19^{\text {th }}$-century reception of Egypt and the Holy Land 'where the literal truth of scripture was thought to be seen' (Rogers, Rogers \& Seymour 1879: 97; Pemble 1987: 122). David Gange has persuasively argued that there was a tradition of 'tying Israelite and Egyptian history together' in archaeology (Gange 2013: 20). Heinrich Schliemann's archaeological discovery of Troy in the 1870 s provided evidence for the reality of the Homeric epic poems and also fuelled the idea that the Old Testament could also be read in archaeological sites in Egypt and the Holy Land. Gange argues that the Book of Exodus acted almost as The Iliad acted for Heinrich Schliemann in directing the early excavations of the Egypt Exploration Fund in the 1880s and framed peoples' attitudes to Egypt (Gange 2013: 179). A. H. Sayce, for example, considered the discovery in 1888 of a cache of letters, the Tell El-Amarna correspondence, from the rulers of Egypt to surrounding powers in around $1500 \mathrm{BC}$ as making it impossible to maintain that literary works, such as we find in the Old Testament, could not have existed in the Mosaic era' (Sayce 1923: 273). Sayce, as we shall see, drew heavily on archaeological research in his compact teaching aids on biblical history and scripture, which influenced wider British understanding of the Holy Land and the Bible. Egypt was the site for many of the most well-known stories in the Old Testament, such as the Exodus of the Israelites, and the Flight of the Holy Family into Egypt at the beginning of the New Testament was understood within the theological context of Egypt in those earlier scripture. The popularity of depicting Egypt fed a genre of scenes in which ancient, modern and biblical visions of Egypt were fused. Long himself was deeply religious and visited Egypt and Syria in 1874; his work from that point on tended to depict religious stories or eastern scenes, often on an epic scale using archaeological objects from the ancient past to give an authentic aura of antiquity.

\section{Long and Anno Domini}

The Russell-Cotes Art Gallery and Museum in Bournemouth has the world's largest collection of paintings by Edwin Longsden Long on public display and were opened in 1919. Long was one of the gallery's founder Sir Merton Russell-Cotes' favourite artists. He collected works by Long when they came for auction after his death in 1891, partly as the artist became more unfashionable and therefore cheaper. It is not known exactly when Russell-Cotes bought Anno Domini, but it was sometime between 1910 and the opening of the gallery in 1919 (Bills 1998: 141). We know that it was on display when Princess 
Beatrice, the youngest daughter of Queen Victoria, opened the gallery to the public. Russell-Cotes recorded the opening ceremony on 8 February 1919 in his memoirs Home and Abroad and noted her appreciation 'with regard to Edwin Long's great works, Anno Domini, Jephtha's Vow and The Chosen Five' (Russell-Cotes 1921: 299). Princess Beatrice had in fact seen Anno Domini in March 1884, soon after its first public display when she, along with her sisters Princesses Victoria and Louise, visited the gallery on New Bond Street specifically to see the work depicting the Holy Family ('Court Circular', London Standard, 12 March 1884). Queen Victoria made a visit to the gallery for the same reason two years later. Yet, when it was again put on public display at Bournemouth in 1919, Long's popularity had waned and he was derided amongst modernist art critics. After a removal from the gallery in the 1940s and 50s (of which more at the end of this paper), Anno Domini is today in its original 1919 position along the whole of a wall in Gallery I. The gold gilt frame reflects the Egyptian setting of the scene as it has lotus and papyrus blossoms embedded and was designed to come apart so that the huge painting (243 x 487 $\mathrm{cm}$ ) could be rolled and moved more easily.

Long had exhibited at the annual Royal Academy show since the 1840s but was only accepted as an Associate of the Royal Academy of Arts after exhibiting The Babylonian Marriage Market (1875). Long's 1874 tour of Egypt and Syria signalled a new direction as he began to produce ancient or biblical scenes through detailed epic - in theme and size - paintings. It was not an original direction as it followed the success of, for example, Edward Poynter's Israel in Egypt (1867). However, the impact of Long's travels in the Middle East on research for his work 'cannot be understated' and he also drew extensively for archaeological detail from ancient Near Eastern and Egyptian source material that was on display in the British Museum as well as contemporary accounts of archaeology, such as from Austen Henry Layard (Bills 1998: 9). His most successful painting was The Babylonian Marriage Market, its critical and public success transformed Long's artistic and financial status. The subject came from the writings of the ancient Greek historian Herodotus, who described the Babylonian marriage market. It was the ideal subject for Long through which to explore female beauty and pagan values. John Ruskin's appraisal of the work in his Academy Notes undoubtedly assisted its critical success:

A painting of great merit, and well deserving purchase by the Anthropological Society. For the varieties of character in the heads are rendered with extreme subtlety; while as a mere piece of painting, the work is remarkable in the 
modern school, for its absence of affectation [. . . (Ruskin, quoted in Bills 1998: 106).

Ruskin's observation of the 'varieties of character in the heads' suggests a reference to phrenology and the practice of reading character in the face or head rather than ethnographic realism despite his opinion of its anthropological value. However, the different racial types depicted have added to its iconography. It was later a source for the spectacular Babylonian sequence in D. W. Griffith's 1916 film Intolerance (1916), in which the mixing of different racial types was used to signify a decadent and sensual ancient Orient. Marriage Market had been commissioned by Edward Hermon MP for 1,700 guineas and was sold at auction in 1882 for $£ 6,625$, including the rights to lucrative copyright for prints and other reproductions, to Thomas Holloway. It is now in the collection of Royal Holloway College, University of London. This was a Victorian sale room record that was unbeaten until 1892 and significantly happened the year before Long was commissioned for Anno Domini.

In 1883 the French Academic artist Gustav Dore died. His work had been exclusively shown in a gallery belonging to fine art publishers Fairless and Beeforth at New Bond Street. The publishers now 'needed a replacement and commissioned Long to produce large scale work for a new gallery' named the Lawrence Gallery (Bills 1998: 16). It was here that Anno Domini, was first exhibited and displayed alongside Michal, a depiction of a placid female beauty typical of Long's work. It was relatively unusual for art in the Victorian period to have an epic New Testament setting, usually such scenes were Old Testament or historical, but prior to the $19^{\text {th }}$ century it was a common artistic trope. The scene shows the 'Flight into Egypt' from the Gospel of Matthew in which Joseph takes his family - the Virgin Mary and Jesus Christ - to Egypt in order to flee King Herod's massacre of baby boys. An early review of it in The Morning Post commented:

The excellent type and variety of feature and the mass of archaeological detail introduced, attest to the research and care which have been resorted to in as great a measure as the numerous incidents depicted show the thought and diligence which have been expended on the work, which is one of the most important, if not the most important, which Mr Long has ever painted. ('Art News' 1883) 
The same paper singled out the 'types of child and mother and father he has desired to present' as being 'realised with care and judgement' (Art News 1883). Unlike Hunt two decades earlier, Long did not offend phrenological ideals. If of interest today, it is generally as illustrative of the archaeological fidelity that characterised artists such as Lawrence Alma-Tadema and Frederick Leighton. The shabtis and amulets sold on the left of the painting are in scrupulous detail, though the position of a pylon style temple in front of the Pyramids in Giza is geographically incorrect. Reviews stressed the archaeological accuracy of detail and the depiction of diverse people. The Standard, for example, pointed to the amass of learning but in so doing thought 'less of the archaeologist than of the student of humanity' ('Mr Long's New Picture', The Standard, 2 January 1884).

A common theme in reviews was that 'Mr Long took his sketches on the spot' with the inference that the people were as real as the artefacts copied from the British Museum or scholarly works ('Art Notes', Manchester Courier and Lancashire General Advertiser 31 December 1887). These reviews echoed Ruskin's comments about The Babylonian Marriage Market though Mark Bills has remarked 'the ethnic origin of many of the painting's figures is not convincing and they look to be rather of European origin' (Bills 1998: 18). Bills is correct on his observation of many of the women in the foreground of the picture; Long depicted a certain type of female beauty continuously. However, the seller of amulets and attendant tending to the sick child who are Black skinned do not appear to conform to this model, neither do the Holy Family. I do not contend that Long has completed an ethnographic survey within Anno Domini. He depicted different racial 'types' in places where people expect them to be: modern Egypt was known for its diversity of peoples, as evidenced in the articles considered in this paper, and this painting projected that diversity onto Biblical Roman Egypt. The Black models add colour to the scene in common with many Oriental paintings of this period, such as Frederick Goodall's The Finding of Moses (1885). A Black servant or attendant is used to 'reinforce Western mythologies of the East' and 'its Black inhabitants' as slaves or at least subservient passive subjects (Llewellyn 2006: 45). The Virgin Mary and Christ Child appear almost luminescent in their fair skin alongside the olive and other colours of flesh of the people surrounding them. This is hard to see on a reproduction of the painting but is startling when viewed in the flesh. It reinforces the commonly held view in Britain that Mary and Jesus conform racially to a white European type in contrast to the idolatrous scrum around them. 
Fairless and Beeforth charged a shilling fee to see the painting alongside some of Long's other work for six years and in 1889 had it engraved as a print by Herbert Bourne (a copy of which is also in the Russell-Cotes Art Gallery and Museum) so that it could be sold as a reproduction. This coincided with a tour of the painting around the UK. A local paper in Bristol, its first port of call, made much of Long's travel to Egypt to give this rendering of a Biblical scene authenticity:

It is well known that Mr Long visited the East in order to become personally acquainted with the manners and customs of the people, and the correctness with which he has painted all the details in his spacious canvas evinces a studious attention to apparently trifling matters. [...] makes his canvas glow with types of female loveliness to be found in the sunny East. (The Western Daily Press, Bristol, 28 September 1889)

Among the places that Anno Domini visited were Bristol, Exeter, Belfast, Leeds, Sunderland, and Manchester. At Manchester, Anno Domini was part of a 'Grand exhibition of celebrated pictures by Edwin Long R. A.' and exhibited alongside Jephtab's Vow, Zeuxis at Crotona and Daughter of Saul for a shilling entrance fee at the Fine Art Institute on Mosley Street, now Manchester City Art Gallery. On return to London, probably in 1891, Fairless and Beeforth renamed it The Unknown God and displayed it at their Gallery of Sacred Art until 1896 (Bills 1998: 141). The current display of Anno Domini at the Russell-Cotes Gallery and Museum alongside many of Long's major works give a glimpse of how the Victorian public saw it.

\section{National and Racial Types}

Anno Domini was and is still displayed alongside The Chosen Five or Zeuxis at Crotona (1885), which depicts the Greek sculptor choosing the perfect body for his sculpture of Aphrodite from five idealized female beauties. These women supposedly provide contrasting features, with different skin tones, hair colour and stances, yet all seem formulaic and similar. This representation of female beauty vividly illustrates Long's vision of the ancient past and archaeological fidelity yet seem at odds with his supposed ethnographic fidelity. This could, of course, be because only a certain type of a female body, the Aphrodite shape and face that Zeuxis is credited with creating, is the acceptable form of feminine beauty for Long and the wider Victorian public. 
In 1887 Long was commissioned by the art house Agnews to produce a series of portraits or metaphorical figures of the different nations, dominions and colonial possessions of the British Empire for the Royal Jubilee of Queen Victoria. The series was called Daughters of Empire and depicted twenty national beauties, which included five of England and fifteen of other countries in alphabetical order: Aden; Bethlehem; India; Wales; Australia; Canada; Cyprus (Ancient: Love's Messenger and Modern); Egypt; England - The Parson's Daughter; England - The Violet; England - The Rose; England - The Primrose; England - The Little Sister of the Poor; Ireland; Jamaica; Malta; Gibraltar; Scotland and Trinidad. England - The Rose was a portrait of Princess Mary of Teck, later Queen Mary and wife of George V, who was from Germany. England - The Primrose was of Lady Randolph Churchill, who was from New York. These portraits of 'English' women reflect an idea of a wider England (or Greater Britain) in which a common Anglo-Saxon type of racial identity could be found, which included Germany and North America as large numbers of northern Europeans from Anglo-Saxon countries had migrated there (Young 2008: 195). This idea had begun in the 1860s, drove imperial expansionist narratives in the 1870s and had become culturally embedded by the 1880s. The series also fitted a 'picture book encyclopedic approach that was clearly developed to have a popular appeal' and all the images had doggerel verse attached (Bills 1998: 19). On that note, unlike Anno Domini, the images were of a small size for one to one reproduction and Agnews owned the copyright to them.

There are few, if any, of the Daughters in public collections and images of them can mainly be traced through sales catalogues. Long sold most of the paintings to Agnews for $£, 600$ and their value dropped dramatically after Long's death in 1891. They served their purpose for the Jubilee and were, as one reviewer noted, 'painted in his well-known style, if hurried and too many' ('Art Notes' 1887). Long appeared to only use European type models, or models that looked as European as possible, but he may again simply have reflected an idealized style of female beauty based on classical statuary, particularly the Aphrodite of Knidos, in form and face through supposedly different models. This form had little sense of any corporeal reality and fitted a long since racialised ideal of the perfect Anglo-Saxon woman (Challis 2010). The Daughters series is clearly very different from Flinders Petrie's scientific search through ancient Egyptian monuments for different racial types that was completed and displayed the same year. However, both Daughters and Petrie's Racial Photographs from the Ancient Egyptian Pictures and Sculptures testify to an interest in 
representing racial and national types of people and an assumption that such a representation is possible. Long's Anno Domini illustrated the assumption that the Virgin Mary and Christ Child were white skinned with (crudely speaking) Northern European features. This was an assumption that many held and some tried to prove with scientific facts. One example of this is a biblical teaching aid The Races of the Old Testament by A. H. Sayce.

\section{Sayce and the Races of the Old Testament}

On first sight Sayce's Races of the Old Testament (1891) seems very different to Anno Domini. The frontispiece is made up of photographs of casts of racial types made by Flinders Petrie from Egyptian monuments, mainly in Karnak, Luxor and Thebes (Figure 4). This 'little book' was published by The Religious Tract Society of London in the popular imprint 'By Paths of Bible Knowledge', which were compact inexpensive books that could be used as teaching aids and prizes in Sunday Schools (Sayce 1923: 273). A year earlier, Modern Discoveries on the Site of Ancient Ephesus by J. T. Wood had been published in the series, which made use of Wood's excavations to provide evidence and visualise St Paul's evangelism at Ephesus and for the New Testament more generally (Challis 2008: 137-8). The Bible was materialised for late Victorian readers and school children through archaeological discoveries in these books much as Long used artefacts to materialise the beginnings of the New Testament in Anno Domini.

The images Sayce used were mainly made by Flinders Petrie who took squeezes from Ancient Egyptian monuments of faces from which he made casts, as well as taking some photographs of racial types in tomb paintings. These casts and photographs of them alongside a contextual essay and table of types comprised the report Racial Photographs from the Ancient Egyptian Pictures and Sculptures (1887), which had been commissioned from Petrie at the British Association for the Advancement of Science (BAAS) annual conference in 1886. The scientist and racial theorist Francis Galton chaired the BAAS committee set up to oversee Petrie's work and the report was presented in the Anthropological Section of the 1887 BAAS conference at which Sayce was President. The casts and photographs were displayed as part of the conference at Manchester and then, under the auspices of the Palestine Exploration Fund, at the South Kensington Museum from October 1887 to early 1888. The Palestine Exploration Fund displayed them as a connection to seeing the faces 
or types of people in the Old Testament (Challis 2013: 105). They were to be used as such in The Races of the Old Testament.

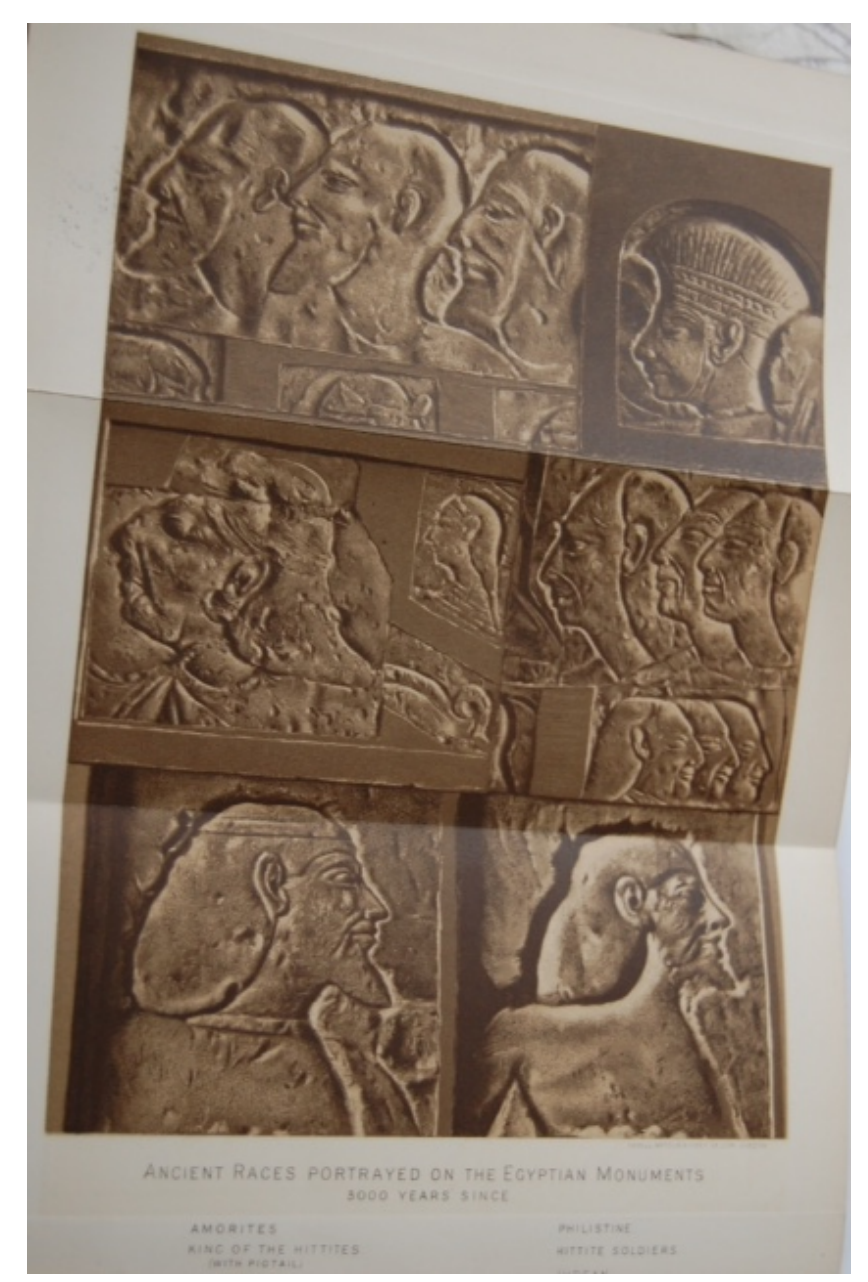

Figure 4: 'Frontispiece' (Sayce 1891).

Archibald Henry Sayce was an Assyriologist, philologist and an archaeologist as well as a clergyman (he was a Fellow at the University of Oxford) and raised the profile of biblical and other areas of archaeology (Gunn, rev. Gurney 2004). Sayce managed to translate 'high [literary and theological] criticism for the average reader' and was particularly interested in Egypt as it related to the history of the Old Testament (Gange 2013: 161). Sayce used Petrie's photographs of casts from monuments 'as the basis' for The Races of the Old Testament (1891) as he was able to put a face to many of the different peoples mentioned in the Old Testament, essentially providing portraits of people in the Bible 
(Sayce 1923: 273). The Races of the Old Testament was one of a number of relatively popular teaching aids for biblical history and scripture that Sayce produced. Sayce was a clergyman and combined his range of expertise to prove the historical validity of the Bible, drawing particularly on archaeological research to do so.

In Races Sayce differentiated race from nation or community and argued that language 'is no test of race', using Jewish people as an example (and repeating several Anti-Semitic tropes in so doing) since wherever they go they learn the local language and sometimes even forget Hebrew but are a distinct race (Sayce 1925: 10). In essence, Sayce defined race as about different physical characteristics of which skull size and shape is among one of the important 'characteristics that distinguish races from one another' (Sayce 1925: 14). Sayce argued that the Egyptians were white and similar to northern Europeans with a redskin due to sun-burn and black or red hair (Sayce 1925: 83). Petrie's Racial Photographs were utilised within Chapter IV: The Semitic Race, in which Sayce defined the various Semitic races and languages and considered how the modern Jewish type has changed since antiquity. He turned to the depiction of tribute bearers on an Assyrian obelisk from 842 $\mathrm{BC}$ that is in the British Museum:

Among them are the servants of Jehu, King of Samaria. Each is portrayed with features which mark the typical Jew of to-day. No modern draughtsman could have designed them more characteristically. The Israelite of the northern kingdom possessed all the outward traits by which we distinguish the pureblooded Jew among his fellow men. (Sayce 1925: 77)

Sayce argued that the modern Jews were so mixed that these sorts of assumptions should not be made today; yet continued with a lengthy description of how to spot contemporary Jewish people who have the purest race, obsessively defining a supposed Jewishness (Cohen 2002). Sayce finished with an emphasis on the importance of these findings since traits 'include not only physical characteristics but mental and moral qualities as well':

More especially does it concern us to know what were the affinities and characteristics, the natural tendencies and mental qualifications of the people to whom were committed the oracles of the Old Testament. Theirs was the race from which the Messiah sprang, and in whose midst the Christian Church was first established. (Sayce 1925: 173) 
The faces of the Bible could literally be seen through the representations on Egyptian monuments and Sayce argued that those who played a significant role in the Bible were showed Aryan or European heritage. This was important for the above reason; it was connected to the identity of Jesus Christ and the formation of Christianity. This was a reason, according to one reviewer, why Races should be in the hands of all Biblical students' ('The Races of the Old Testament', The Inverness Courier 1892).

To prove that this evidence was scientific, Sayce argued for the fidelity in which Egyptian artists pictured the faces of the prisoners led into Egypt, comparing them to that scientific absolute, the photograph:

The Egyptian artist had an innate gift for portraiture; he seized at once the salient traits in an individual face, and reproduced them with almost photographic fidelity. Doubtless at times he may have exaggerated some striking feature in the head of a foreigner [. . .]. But such exaggerations only bring into stronger relief a racial peculiarity, and it may after all be questioned whether the exaggeration is as great as it seems. (Sayce 1925: 4)

This was an aspect stressed by reviews of the book. The Leeds Mercury repeated the above paragraph within its review and praised the use of illustrations as portraying the different races 'as seen 5000 years ago on Egyptian Monuments' ('Literature. New Books and New Editions’ 1891).

\section{Aftermath}

Sayce warned about racial generalizing, especially connecting intellectual ability with physical characteristics, yet forgot such generalization in making highly racist statements. In commenting on depictions of Nubians, he described 'the Negro' as 'simple' and in character 'indolent, superstitious, affectionate and faithful' (Sayce 1925: 145). The Races of the Old Testament was republished in 1925 and is still available in full on the internet, downloadable from a white supremacist website in the USA, where it is used to verify the supposed superiority of Christian white races. On its publication Races was reviewed as a 'gift' or 'prize book' and was likely to have been ubiquitous in Sunday Schools in the 1890s and early twentieth century ('Gift Books' 1891). ${ }^{4}$ It is racist and is still used as a tool of

\footnotetext{
${ }^{4}$ I have also heard anecdotally that it was found in one Synagogue school in the 1970s.
} 
racism today. A product of the attitudes of its time, the ubiquity of Races as a teaching aid or gift also illustrates how mainstream, even unthinking, these attitudes were.

Anno Domini suffered a very different fate in the 1950s, the height of reaction against Victorianism, when it was loaned to Summerbee Secondary School, Bournemouth for display in the main hall with a wall built especially for it. It was loaned to the school in 1953 but hit the press after comments by a school inspector in 1956. When first loaned by the Russell-Cotes Museum and Art Gallery, probably after storage during World War Two, the headmaster of the school A. W. Legge ordered the painting to be draped due to the 'nude and semi nude [sic.] women in foreground' ('Dispute on school painting' 1956). A subsequent inspection in 1956, found that it 'had served its purpose' and should be removed; though it was, in the event, too costly to remove for a number of years. The Bournemouth Echo reported the controversy as 'between those who consider the picture as a last bastion against Braque, a swollen hunk of Victorian vulgarity, or just a little bit "naughty" for kiddies to look at' ('That picture spells trouble' 1956). Norman L. Silvester, curator of Russell-Cotes in the 1950s, thought that the painting had a purpose to serve in the school and the wider community. In a letter to a councillor in response to the headmaster's request to drape Anno Domini, Silvester writes (though the paragraphs are crossed out in pencil):

I think that the Headmaster is taking an extreme view of the influence of such a picture; and, that, with the Christian approach, the emphasis on the central theme of the child Christ as the healer unrecognised by the Egyptian crowds far outweighs any suggestion of indecency in the background figures.

As I understand the school is to be used as a community centre when not in use as a school, perhaps the picture might be curtained and shown only to adults at evening functions.

I had hoped that an open Bible might have been displayed on a desk in front of the picture so that those who have never been educated to read it might be encouraged to commence (Silvester 1953).

The curator at least believed Anno Domini to still have an educational and religious mission, but both this mission envisaged through art and Long's popular Victorian style were deeply unfashionable. It is ironic that a piece of Victorian art scandalised people in the 1950s with its depictions of nude women, given the term 'Victorian' was often derivatively 
(and inaccurately) used as a byword for prudity and moral convention. The racialised vision of the Holy Family and Egypt was not an issue and not even commented upon.

In both Anno Domini and The Races of the Old Testament racial distinctions were not simply based on skin colour but 'inscribed on the body' through visual and/or literary analysis in 'myriad ways' (Grindhart 2008: 228). The construction of race in late $19^{\text {th }}$-century Britain is complicated and the production of art reflecting wider racial tropes needs to be placed within a wider context than could be covered in this paper. However, Long, Sayce, and Petrie shared an interest in racial typologies that were typical of culture and science in Britain during the 1880s. Artists, archaeologists and biblical scholars used archaeological discoveries and painterly tropes around antiquity to visualise their ideas around race, the Bible and Ancient Egypt.

\section{Acknowledgements}

Many thanks to Duncan Walker, Curator at the Russell-Cotes Art Gallery and Museum, Bournemouth, and his colleagues for access to their archives and time.

Competing Interests: The author declared no potential conflicts of interests with respect to the research, authorship, and/or the publication of this paper.

\section{REFERENCES}

'Art in January', The Magazine of Art, January 1884, xiv.

'Art News', The Morning Post, London, 31 December 1883.

'Art Notes', Manchester Courier and Lancashire General Advertiser, 1 June 1887.

'Art Notes', The Western Daily Press, Bristol, 28 September 1889.

'Court Circular', London Standard, 12 March 1884.

'Gift Books', The Morning Post, London, 18 November 1891.

'Literature: New Books and New Editions', The Leeds Mercury, 28 December 1891.

'Mr Long's New Picture', The Standard, London, 2 January 1884.

'The Races of the Old Testament', The Inverness Courier, 9 February 1892.

Bills, M 1998, Edwin Longsden Long RA, London: Cynus Arts. 
Bills, Mark (2001), 'Display and Exhibition in the Victorian Era', in Bills M (ed.) Art in the Age of Queen Victoria. A Wealth of Depictions, Bournemouth: Russell-Cotes Art Gallery and Museum, 42-52.

Boime, A 2002, 'William Hunt's The Scapegoat: Rite of Forgiveness / Transference of Blame', The Art Bulletin, 84/1, 94-114.

Challis, D 2008, From the Harpy Tomb to the Wonders of Ephesus. British Archaeologists in the Ottoman Empire 1840-1880, London: Duckworth.

Challis, D 2010, "The Ablest Race": Ancient Greek Art and Victorian Racial Theory' in Bradley M (ed.), Classics and Imperialism in the British Empire, Oxford: Oxford University Press, 94-120.

Challis, D 2013, The Archaeology of Race. The Eugenic Ideas of Flinders Petrie and Francis Galton, Bloomsbury: London.

Cohen, D 2002, 'Who was Who? Race and Jews in Turn of the Century Britain', The Journal of British Studies, 41/4: 460-483.

Cowling, M 1989, The Artist as Anthropologist. The Representation of Type and Character in Victorian Art, Cambridge: Cambridge University Press.

'Dispute on School Painting. Removal Advised by Inspector. From Our Correspondent in Bournemouth', November 12, The Times, 13 November 1956.

El Hage, B 2013, 'A Tour in the East', in Gordon S (ed.) Cairo to Constantinople. Francis Bedford's Photographs of the East, London: Royal Collections Trust, 37-53.

Esposito, D 2003, 'From Ancient Egypt to Victorian London: The Impact of Ancient Egyptian Furniture on British Art and Design 1850-1900', The Journal of the Decorative Arts Society 1850 to the Present, No. 27, 80-93.

Gange, D 2013, Dialogues with the Dead: Egyptology in British Culture and Religion, 1822 - 1922, Oxford: Oxford University Press.

Grindhart, M P 2008, 'Introduction: Imaging Blackness in the Long Nineteenth Century', Visual Resources: An International Journal of Documentation, 24/3, 225-232.

Hanley, H J M 2010, 'Through British Eyes. Paintings from the Doha Orientalist Museum', The British Art Journal, Vol. II No. 2 (2010/11), 6-21.

Llewellyn, B 2006, 'Observations and Interpretation: Travelling Artists in Egypt', Black Victorians. Black People in British Art, Aldershot: Lund Humphries, 35-45.

Loftie, W J 1884, 'Sketches in Egypt', The Magazine of Art, January 1884 15-20.

Loftie, W J 1884, 'Egyptian Types', The Magazine of Art, January 1884, 57-65. 
Moscrop, J J 2000, Measuring Jerusalem: The Palestine Exploration Fund and British Interests in the Holy Land, Leicester: Leicester University Press.

Nochlin, L 1983, 'The Imagined Orient', Art in America, May 1983: 118-131.

Pemble, J 1987, The Mediterranean Passion. The Victorians and Edwardians in the South, Oxford: Oxford University Press.

'Rebekah at the Well', Illustrated London News, 18 December 1880, Issue 2170: 597.

Rogers, E T, Rogers, M E \& Seymour, G C 1879, 'The Land of Egypt. Chapter III', The Art Journal, Vol. 5, 97-100.

Rogers, E T, Rogers, M E \& Seymour, G C 1879, 'The Land of Egypt. Chapter XI', The Art Journal, Vol. 5, 356-359.

Russell-Cotes, M 1921, Home and Abroad. An Autobiography of an Octogenarium. Bournemouth: Privately Printed.

Sayce, A H 1923, Reminiscences, London: Macmillan.

Sayce, A H 1925, The Races of the Old Testament, London: Whitefriars Press Ltd.

Scott, D 1988, 'The Literary Orient', in Thompson, J (ed.), The East. Imagined, Experienced, Remembered. Orientalist Nineteenth Century Painting, Dublin: The National Gallery of Ireland, 3-17.

Silvester, N L 1953. Letter to Councillor Meader, Russell-Cotes Art Gallery and Museum, 14 September 1953. Russell Cotes Museum and Art Gallery Archives.

'That picture spells trouble. Fight Fares up at school nudes' (1956), Bournemouth Echo, exact date unknown. Press Clippings Book, Russell-Cotes Museum and Gallery Archives.

'The First Born', Illustrated London News, 2 August 1862, Issue 1157: 145.

Young, R J C 2008), The Idea of English Ethnicity, Oxford: Blackwell Publishing

\section{FURTHER READING}

Cowling, M 2001, 'Art in the Age of Queen Victoria', in Bills M (ed.) Art in the Age of Queen Victoria. A Wealth of Depictions, Bournemouth: Russell-Cotes Art Gallery and Museum, 12-41.

Marsh, J 2006, 'The Black presence in British Art 1800 - 1900. Introduction and Overview', Black Victorians. Black People in British Art, Aldershot: Lund Humphries, 12-22. 
Pointon, M R 1989, The Artist as Ethnographer: Holman Hunt and the Holy Land' in Pointon M R (ed.), Pre-Raphaelites Reviewed, Manchester: Manchester University Press, $22-44$.

Rogers, E T, Rogers, M E \& Seymour, G C 1879, 'The Land of Egypt. Chapter I', The Art Journal, Vol. 5, 37-40.

Thompson, J 1988, 'Mapping the Mind - The Quest for Eastern Metaphors and Meaning', in Thompson, J (ed.), The East. Imagined, Experienced, Remembered. Orientalist Nineteenth Century Painting, Dublin: The National Gallery of Ireland, 18-35.

Figures: All images have been produced by artists or authors who have been dead for over seventy years and are therefore free from known copyright restrictions. They are reproduced under the Creative Commons: No Copyright definition: 'This work has been identified as being free of known restrictions under copyright law, including all related and neighboring rights. You can copy, modify, distribute and perform the work, even for commercial purposes, all without asking permission.' https://creativecommons.org/publicdomain/mark/1.0/deed.en [accessed 01/05/2019] 